\title{
IMPLEMENTASI PRAKTIK KERJA LAPANGAN \\ PESERTA DIDIK KELAS XII TAHUN PELAJARAN 2019/2020 SMK MUHAMMADIYAH 3 KARANGANYAR
}

\author{
Choyrul Anwar, Yuyun Estriyanto, Muhammad Akhyar, Ngatou Rohman \\ Program Studi Pendidikan Teknik Mesin, FKIP, Universitas Sebelas Maret \\ Kampus V UNS Pabelan, Jl. Ahmad Yani 200, Surakarta \\ E-mail:choyrulbf19@gmail.com
}

\begin{abstract}
ABSTRAK
Tujuan dari penelitian ini adalah untuk mengetahui sejauhmana pelaksanaan program PKL dengan mengevaluasi aspek konteks, input, proses dan produk. Tempat untuk melakukan penelitian ini di SMK Muhammadiyah 3 Karanganyar jurusan Teknik Kendaraan Ringan kelas XII. Penelitian ini menggunakan metode penelitian deskriptif evaluatif model CIPP (Context, Input, Process, Product) dengan menggunakan data kuantitatif serta kualitatif dan dokumentasi sebagai pendukung. Sampel penelitian ini diambil menggunakan teknik purposive sampling yaitu peserta didik, pembimbing industri serta guru pembimbing. Teknik pengumpulan data menggunakan kuesioner untuk mencari data utama serta wawancara dan dokumentasi sebagai pendukung. Validitas yang digunakan dalam penelitian ini adalah validitas logika. Teknik analisis kuesioner menggunakan teknik analisis rata-rata yang dinilai berdasarkan kriteria penilaian. Hasil evaluasi secara keseluruhan menunjukkan bahwa pelaksanaan program PKL berjalan dengan baik dan lancar. Pertama, evaluasi aspek konteks secara keseluruhan masuk dalam kategori baik sekali. Kedua, evaluasi aspek input secara keseluruhan masuk dalam kategori baik sekali. Ketiga, evaluasi aspek proses secara keseluruhan masuk dalam kategori baik. Keempat, evaluasi aspek produk secara keseluruhan masuk dalam kategori baik sekali.
\end{abstract}

Kata kunci : Implementasi, CIPP, Praktik Kerja Lapangan

\section{PENDAHULUAN}

Pendidikan sangat berperan untuk menentukan masa depan bangsa. Suatu bangsa tanpa adanya kegiatan pendidikan, maka bangsa tersebut tidak bisa berkembang dan maju sesuai dengan yang sudah direncanakan oleh pemerintah. Saat proses pendidikan berlangsung yang terlibat dalam proses pendidikan akan mengalami masalah yang menghambat sehingga perlu adanya teknik untuk mengatasi masalah tersebut. Masalah dalam pendidikan dibedakan menjadi beberapa yaitu masalah ringan, masalah sedang serta masalah berat. Setiap masalah perlu adanya solusi untuk menyelesaikan dan memperbaiki agar bisa berubah menjadi suatu hal yang positif.

Menurut (Burhan et al., 2017), SMK yaitu bagian dari pendidikan menengah dimana lulusannya disiapkan khusus agar bisa terjun ke dunia kerja sesuai bidangnya. (Sudira, 2012) bahwa didalam pendidikan kejuruan termuat materi umum yang mempunyai sifat adaptif maupun normatif serta pelatihan 
yang bersifat praktik untuk mengembangkan kemampuan dari berbagai pekerjaan yang ada. Artinya pendidikan kejuruan melatih manusia mempunyai keterampilan bekerja yang bisa digunakan untuk memasuki dan berkembang di dunia kerja. Pernyataan tersebut dikuatkan oleh (Sofyan, 2015) pendidikan kejuruan memiliki tujuan yang khusus yaitu agar siap untuk terjun ke dunia kerja yang relevan dengan bidang keahliannya. Tenaga pendidik dituntut untuk memahami dan menguasai kompetensi sebagaimana dipersyaratkan. Sebagai tenaga pendidik yang profesional di bidang pendidikan kejuruan, harus memahami konsep, prinsip, dan karakteristik pendidikan kejuruan. Seperti pendapat dari (Hasanah, 2015), SMK menjadi bagian dari sistem pendidikan nasional mempunyai tujuan membentuk kecakapan hidup, salah satunya melatih peserta didik untuk menguasai serta mematangkan keterampilan yang dibutuhkan oleh dunia kerja.

Berdasarkan data dari Badan Pusat Statistika No. 91/11/Th.XXII, 05 November 2019 memperlihatkan jumlah pengangguran pada Agustus 2019 mencapai 7,05 juta orang. Tingkat pengangguran tertinggi menurut tingkat pendidikan didominasi oleh lulusan SMK $(10,42 \%)$ dan diikuti oleh SMA (7,92\%), Diploma (5,99\%), Universitas $(5,67 \%)$, sedangkan untuk SMP $(4,75 \%)$ dan SD $(2,41 \%)$. Mengacu pada hasil data ini, tingkat penyerapan lulusan Sekolah Menengah Kejuruan di dunia kerja masih relatif rendah. Menurut (Riyanto et al., 2017) salah satu faktor naiknya angka pengangguran yaitu tidak terserapnya lulusan oleh dunia industri karena minimnya lapangan pekerjaan serta tidak mempunyai kualifikasi maupun kompetensi yang dibutuhkan oleh pasar kerja.

Sedangkan menurut (Muladi et al., 2018) banyak lulusan dari SMK tidak semuanya mudah diserap oleh industri karena diasumsikan oleh visi dan tujuan. Ini karena di SMK terdapat : (1) kesenjangan keterampilan karena ketidaksesuaian dalam program dan kebutuhan serta tuntutan industri SMK; (2) kelemahan dalam kurikulum; (3) guru yang tidak kompeten dengan pelatihan dan pengalaman industri yang terbatas; (4) sejumlah besar lulusan tahunan mengarah ke kompetisi yang tinggi di antara lulusan; dan (5) fasilitas dan infrastruktur pembelajaran yang tidak memadai di SMK. Hal tersebut menyiratkan bahwa SMK saat ini masih menghadapi tantangan pendidikan yang pada umumnya terkait dengan terbatasnya alat praktik yang digunakan, sedikit praktik, dan lingkungan belajar yang ada disekolahan tidak sesuai kondisi tempat kerja. Menurut (Hasan et 
al., 2015) keterampilan yang dikeluarkan oleh sekolah tidak setara dengan persyaratan industri dan layanan. Ini adalah masalah yang masih terjadi hingga hari ini di mana peserta didik sulit mendapatkan pekerjaan karena sebagian besar pemberi kerja tidak melihat relevansi kursus dan keterampilan yang dimiliki oleh peserta didik. Ini mungkin disebabkan oleh perbaikan yang lambat dan kurangnya fasilitas terbaru dalam melatih peserta didik.

Jurusan Teknik Kendaraan Ringan (TKR) memberikan peserta didik kemampuan bidang otomotif yang menitik beratkan pada penguasaan secara teknis mengenai sistem kendaraan ringan. Salah satu persyaratan untuk bisa lulus dari SMK adalah melakukan kegiatan Praktik Kerja Lapangan di dunia kerja sesuai dengan bidangnya dalam jangka waktu tertentu. Saat melakukan PKL di dunia industri peserta didik perlu melakukan adaptasi dengan dunia industri itu sendiri. Karena kegiatan di dunia industri dengan kegiatan di sekolah berbeda. Perbedaan yang sangat mencolok adalah di dunia industri murni pekerjaan yang harus dikerjakan yang outputnya langsung ke pelanggan sedangkan saat di sekolah yang sifatnya latihan atau repetisi untuk memantapkan kompetensi yang sudah dikuasai oleh peserta didik dengan menggunakan objek pekerjaan milik sekolah.
Jurusan TKR harus memperhatikan penguasaan kompetensi siswa dan penerapan ilmu dalam kehidupan seharihari. Menurut (Abdulmajid, 2015) keefektifan proses belajar pendidikan kejuruan ada dua hal yang sangat penting, yaitu: proses belajar mengajar untuk mendapatkan ilmu pengetahuan mengenai bidang kejuruan dan belajar secara kontekstual adalah langkah untuk menerapkan pengetahuan tersebut. Dunia industri memerlukan SDM yang berpendidikan, andal, serta bisa memenuhi tantangan. Industri juga memerlukan suatu program yang bisa membantu tenaga kerja yang profesional untuk mengikuti kemajuan teknologi. Hal tersebut memerlukan serangkaian persiapan untuk menghadapinya. Menurut (Yoto \& Widiyanti, 2017) cara yang efektif yaitu membuat kerjasama antara industri dan suatu lembaga pendidikan formal yaitu Sekolah Menengah Kejuruan. Setiap SMK harus bekerjasama dengan sektor bisnis dan industri yang relevan dengan jurusan yang ada.

Menurut (Musthofa et al., 2017) ada faktor yang bisa memaksimalkan SDM yaitu membangun suatu sistem pendidikan yang bersifat fleksibel, mengembangkan serta memperbarui keterampilan yang dibutuhkan dan meningkatkan kemampuan dalam kerja. Oleh karena itu diperlukan suatu jembatan bagi SMK agar dapat 
mengikuti perkembangan yang ada di Industri dimana peserta didik dapat mengembangkan dan memperbarui keterampilan sesuai dengan perkembangan teknologi sehingga mampu mematangkan kemampuan kerja sesuai kebutuhan yang ada di industri. Menurut (Sardimanto et al., 2017) yang mempengaruhi kesuksesan PKL adalah kualitas hubungan kerjasama antara pihak internal dengan pihak eksternal. Hal tersebut benar karena jika antara industri dengan sekolahan memiliki hubungan yang erat bisa menciptakan kerjasama yang baik termasuk industri mendukung program-program dari sekolah salah satunya mengenai Praktik Kerja Lapangan di sekolah kejuruan. Langkah yang harus dilakukan oleh sekolah adalah membuat MoU dengan pihak industri agar jalinan kerjasama antara kedua belah pihak bisa terjalin kerjasama yang baik. Tentunya kerjasama tersebut bisa menguntungan kedua belah pihak.

Kesuksesan PKL juga dipengaruhi oleh kelayakan industri itu sendiri. Seperti dalam penelitiannya (Edi et al., 2017) mendiskripsikan sebelum diadakanya kerjasama antara sekolah dan dunia industri terlebih dahulu sekolah harus melaksanakan evaluasi mengenai kelayakan industri. Kelayakan industri tempat PKL bagi peserta didik SMK memiliki kriteria sendiri untuk masingmasing sekolah. Beberapa kriteria yang ada adalah kelayakan alat yang dipakai dan jarak tempat PKL dari sekolah. Ada industri yang dinilai layak untuk tempat PKL ataupun tidak layak untuk dilakukuan PKL. Industri yang telah memenuhi kriteria yang dicari oleh sekolah untuk tempat PKL maka sekolah akan menerjunkan pesera didik industri tersebut dengan sebelumnya membuat MoU dengan pihak industri untuk melakukan PKL di industri tersebut. Alasan penelitian ini dilaksanakan adalah karena di SMK Muhammadiyah 3 Karanganyar Jurusan Teknik Kendaraan Ringan belum pernah dilakukan penelitian evaluasi mengenai program PKL menggunakan model evaluasi CIPP serta memberi informasi kepada sekolah untuk lebih bisa memaksimalkan lagi program PKL agar lebih baik lagi dalam pelaksanaannya.

\section{METODE PENELITIAN}

Tujuan dari penelitian ini untuk mengevaluasi program PKL yang ada di Jurusan Teknik Kendaraan Ringan SMK Muhammadiyah 3 Karanganyar. Penelitian ini adalah penelitian evaluasi dengan menggunakan metode CIPP yang untuk mengetahui tingkat pelaksanaan program PKL ditinjau dari aspek Context, Input, Process serta Product yang ada di SMK Muhammadiyah 3 Karanganyar. Menurut (Muyana, 2017) yang menjadi sasaran dari evaluasi context berfungsi menganalisa 
status dari objek yang akan dievaluasi dengan menyeluruh sehingga bisa menggambarkan fenomena dalam bentuk deskripsi yang berkaitan dengan karakteristik suatu lingkungan yang akan dievaluasi dalam program. Evaluasi Input dilaksanakan dengan mengkaji pendekatan yang terkait sehingga bisa mendukung pelaksanaan program. Evaluasi proses mengacu dengan apakah pelaksanaan program berjalan sesuai dengan yang sudah direncanakan. Evaluasi produk memiliki tujuan untuk mengukur, menafsirkan, dan memberikan nilai capaian dari suatu kegiatan.

Menurut (S. \& J. C. Arikunto, 2009) prosedur yang dilakukan adalah menemukan permasalah yang ada, menyusun proposal, menyusun instrumen, mengumpulkan data, menganalisa data serta mengambil kesimpulan. Sumber data dalam penelitian ini meliputi pembimbing industri, guru pembimbing serta peserta didik. Teknik pengambilan sampel dipilih oleh peneliti dalam penelitian ini adalah purposive sampling. (S. Arikunto, 2006), cara pengambilan sampel pada teknik purposive sampling tidak berdasarkan random, daerah atau strata, melainkan berdasarkan adanya suatu pertimbangan yang berfokus pada tujuan tertentu. Jadi jumlah sampel dari peserta didik berjumlah 145 orang. Jumlah sampel pembimbing dari industri Berjumlah 9 orang yang diambil dari tiga industri besar, tiga industri menengah dan tiga industri kecil. Sedangkan untuk guru pembimbing Praktik Kerja Lapangan jumlah sampel yang diambil yaitu keseluruhan dari jumlah populasi yaitu 11 orang.

Teknik uji validitas instrumen yang digunakan adalah teknik fact finding. Jenis validitas dari penelitian ini adalah validitas logika dimana instrumen dinyatakan valid berdasarkan analisis rasional dan penalaran peneliti dengan cara konsultasi kepada ahli (expert judgement). Data yang diperoleh melalui kuesioner menggunakan skala semantic differential dengan 5 alternatif jawaban setiap pertanyaan dengan nilai terendah 1 dan nilai tertinggi adalah 5 . Analisis data dalam penelitian ini menggunakan analisis rata-rata dengan menghitung rata-rata setiap komponen evaluasi. Berikut ini rumus yang digunakan untuk menghitung rata-rata :

$\%=\frac{\sum x}{\sum x \max } \times 100 \%$

Keterangan :

$\%=$ persentase pencapaian

$\sum \mathrm{x}=$ penjumlahan skor pada suatu item

$\sum \mathrm{x} \max =$ penjumlahan skor maksimum pada suatu item

Setelah hasil penelitian diperoleh dalam bentuk persentase pencapaian, kemudian di interprestasikan berdasarkan skala penilaian menurut (Riduwan, 2006) 


\begin{tabular}{llc}
\hline No & Nilai $(\%)$ & Keterangan \\
\hline 1 & $81-100$ & Baik Sekali \\
\hline 2 & $61-80$ & Baik \\
\hline 3 & $41-60$ & Cukup Baik \\
\hline 4 & $21-40$ & Kurang Baik \\
\hline 5 & $0-20$ & Tidak Baik \\
\hline
\end{tabular}

Kemudian hasil penelitian akan dianalisis mengunakan analisis statistik deskriptif berdasarkan data kuantitatif yang telah dikumpulkan melalui kuesioner dari responden penelitian. Serta didukung dengan wawancara dan dokumentasi sebagai penguat. Metode penyajian hasil penelitian dilakukan secara deskriptif.

\section{HASIL DAN PEMBAHASAN}

\section{Evaluasi Konteks (Context Evaluation)}

Ada tiga sub variabel dari evaluasi konteks pada pelaksanaan PKL di SMK Muhammadiyah 3 Karanganyar yaitu :

Tabel 4.1. Deskripsi Hasil Rata-Rata Aspek Evaluasi Context

\begin{tabular}{llcc} 
No. & Indikator Evaluasi & $\begin{array}{c}\text { Rata-Rata per } \\
\text { Komponen }\end{array}$ & $\begin{array}{c}\text { Rata-Rata } \\
\text { Aspek }\end{array}$ \\
\cline { 1 - 2 } 1. & Tujuan PKL & 94,60 & \\
\cline { 1 - 2 } 2. & $\begin{array}{l}\text { Karakteristik Peserta } \\
\text { Didik }\end{array}$ & 76,77 & 84,67 \\
\cline { 1 - 2 } 3. & Sarana dan Prasarana & 82,03 & \\
\hline
\end{tabular}

Hasil penelitian dari tabel 4.1 ditampilkan dalam diagram batang berikut :

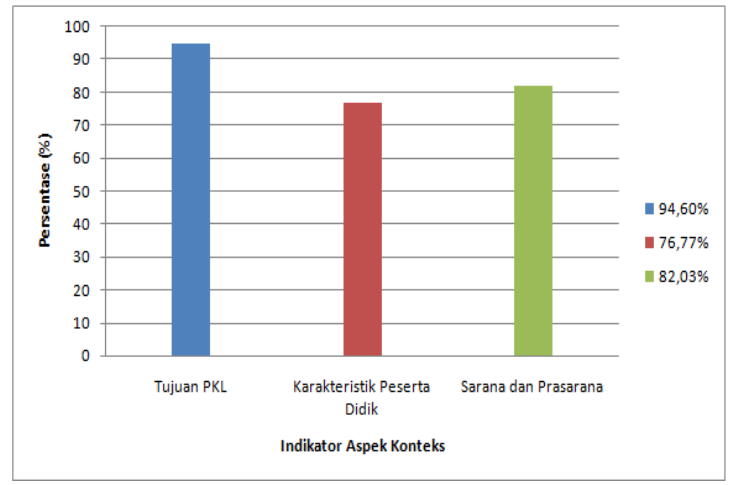

Gambar 4.1. Capaian rata - rata nilai pada aspek evaluasi konteks

Berdasarkan hasil penelitian mengenai evaluasi konteks pelaksanaan PKL di SMK Muhammadiyah 3 Karanganyar pada indikator tujuan PKL mendapatkan rata-rata $94,60 \%$, karakteristik peserta didik memperoleh rata-rata $76,77 \%$ serta sarana dan prasarana mendapatkan rata-rata $82,03 \%$. Rata-rata evaluasi konteks secara keseluruhan adalah $84,67 \%$. Angka tersebut menunjukkan bahwa evaluasi konteks program PKL di SMK Muhammadiyah 3 Karanganyar termasuk kategori baik sekali.

a. Tujuan program PKL yang telah ditetapkan oleh sekolah termasuk dalam kategori baik sekali dan bisa diterima oleh pihak industri yang bekerjasama dengan sekolah sehingga tujuan program PKL bisa digunakan sebagai acuan untuk menjalankan program. Tujuan tersebut adalah membangun kerja sama antara 
SMK Muhammadiyah 3 dengan

DU/DI, meningkatkan wawasan

peserta didik tentang ilmu/jurusan

yang digelutinya, meningkatkan

ketrampilan peserta didik, menyingkrokan antar teori dan praktik dilapangan dan menyiapkan peserta didik ke dunia kerja.

b. Karakteristik peserta didik secara keseluruhan termasuk kategori baik. Hal tersebut menunjukkan bahwa peserta didik siap untuk melakukan program PKL. Walaupun perlu ada peningkatan dalam hal karakteristik peserta didik dari segi kesiapan pengetahuan, keterampilan serta minat peserta didik dengan cara memaksimalkan aspek input serta memberikan motivasi sebelum melakukan program PKL agar peserta didik lebih siap untuk mengikuti program PKL.

c. Sarana dan prasarana yang berada di sekolah dan industri yang bekerjasama dengan sekolah secara keseluruhan termasuk kategori baik sekali dan tempat yang digunakan nyaman untuk melakukan pekerjaan.. Kedua belah pihak harus memastikan sarana dan prasarana yang akan digunakan untuk program PKL harus bisa menunjang program karena sarana dan prasarana merupakan komponen penting dari program PKL. Sejalan dengan hasil penelitian (Burhan et al., 2017) infrastruktur sangat mempengaruhi kualitas untuk menggambarkan identifikasi dan analisis masalah dalam pelaksanaan PKL pada tahap implementasi. Sarana dan prasarana yang mendukung program PKL maka akan mendukung keberhasilan tujuan dari program yang diharapkan oleh pihak sekolah dan industri.

\section{Evaluasi Masukan (Input Evaluation)}

Ada tiga sub variabel dari evaluasi input pada pelaksanaan PKL di SMK Muhammadiyah 3 Karanganyar yaitu :

Tabel 4.2. Deskripsi Hasil Rata-Rata Aspek Evaluasi Input

\begin{tabular}{llcc}
\hline No. & Indikator evaluasi & $\begin{array}{c}\text { Rata-rata per } \\
\text { komponen }\end{array}$ & $\begin{array}{c}\text { Rata-rata } \\
\text { aspek }\end{array}$ \\
\hline 1. & Rencana PKL & 86,11 & \\
2. & Prosedur PKL & 85,43 & 83,14 \\
3. & Penyiapan Kompetensi & 77,89 & \\
\hline
\end{tabular}

Hasil penelitian dari tabel 4.2 ditampilkan dalam diagram batang berikut : 


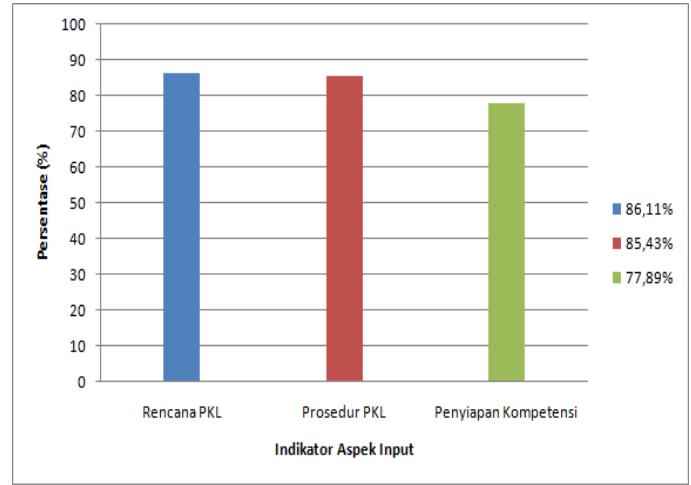

Gambar 4.2. Capaian rata - rata nilai pada aspek evaluasi masukan

Berdasarkan hasil penelitian mengenai evaluasi input pelaksanaan PKL di SMK Muhammadiyah 3 Karanganyar pada indikator rencana yang dilakukan sekolah dengan industri mendapatkan rata-rata $86,11 \%$, Prosedur yang dilakukan sekolah untuk peserta didik dalam melakukan program PKL memperoleh rata-rata $85,43 \%$ serta penyiapan kompetensi peserta didik mendapatkan rata-rata $77,89 \%$. Ratarata evaluasi input secara keseluruhan adalah 83,14\%. Angka tersebut menunjukkan bahwa evaluasi input program PKL di SMK Muhammadiyah 3 Karanganyar termasuk kategori baik sekali.

a. Rencana yang dilakukan sekolah dengan industri dalam program PKL secara umum termasuk kategori baik sekali. Hubungan sekolah dengan industri harmonis karena adanya MoU yang sudah disepakati. Untuk meningkatkan kerjasama sekolah dan industri dengan mengadakan MoU antara sekolah dan industri yang diperbaruhi setiap setahun sekali. Kriteria pemilihan industri tempat PKL dijalankan adalah letaknya strategis, sumber daya yang dimiliki industri baik, sarana dan prasarana mendukung serta mau diajak untuk bekerjasama menjalankan program PKL. Ada kriteria yang paling penting yaitu kompetensi yang ada di industri harus sesuai dengan kompetensi yang ada di sekolah.

b. Prosedur yang dilakukan sekolah untuk peserta didik dalam melakukan program PKL termasuk kategori baik sekali. Agar program PKL bisa berhasil sesuai dengan tujuan yang sudah ditetapkan yang dilakukan sekolah adalah dengan membuat kepengurusan untuk mengurusi program PKL agar lebih terorganisir, membuat sistem pengolahan program PKL, menjaga komunikasi dengan industri, kompetensi yang ada di industri relevan dengan jurusan TKR, mengadakan pembekalan PKL untuk peserta didik sebelum PKL dimulai, menyampaikan kisikisi kompetensi yang ada di sekolah ke industri, dengan 
bekerjasama dengan industri yang sudah dipilihkan oleh sekolah maka peserta didik akan lebih siap masuk ke industri karena sudah sesuai dengan kempetensi yang diberikan sekolah. Langkah yang dilakukan sekolah untuk melakukan program PKL adalah : (1) Melakukan kerjasama dengan industri mitra dengan membuat MoU yang diperbaruhi setiap satu tahun sekali; (2) Penyiapan pengetahuan dan keterampilan oleh guru tamu dari industri sesuai dengan kompetensi yang ada selama 2 bulan sebelum PKL dimulai; (3) Pembekalan sebelum program PKL dilaksanakan dengan materi standart industri yang diberikan oleh guru tamu industri, sistem penilaian oleh kurikulum, tata tertib oleh kesiswaan, sanksi jika ada pelanggaran oleh BP serta teknik pelaksanaan program PKL di industri); (4) Penyerahan peserta didik ke industri oleh guru pembimbing; (5) Pelaksanaan program PKL di industri; (6) Monitoring setiap bulan sekali sesuai dengan surat tugas dari sekolah; (7) Pembuatan laporan PKL oleh peserta didik; (8) Penarikan peserta didik dari industri; (9) Pengujian laporan PKL oleh guru pembimbing; (10) Laporan dari panitia program PKL. Langkah yang dilakukan sekolah dengan melibatkan industri sangat tepat karena industri juga memiliki peran andil yang sangat besar dalam keberjalanan program PKL nanti. Dengan melibatkan industri dalam melakukan perencanaan program PKL maka sekolah akan mendapatkan masukan dari industri yang bisa digunakan oleh sekolah untuk memaksimalkan perencanaan sebelum proses program PKL dilakukan. Hal tersebut sejalan dengan temuan penelitian yang dilakukan oleh (Setiyaningrum, 2018) perlu melibatkan pihak DU/DI terkait sinkronisasi kurikulum, penyelenggaraan penilaian didesain dan dilakukan bersama oleh industri dan sekolah sehingga akan tercipta link and match serta pada saat sosialisasi perwakilan dari industri lebih bisa berbagi informasi mengenai gambaran besar yang ada di industri serta memotivasi peserta didik agar lebih serius untuk melakukan program PKL khususnya dalam hal tata krama di dunia kerja. 
c. Penyiapan kompetensi peserta didik sebelum melakukan program PKL termasuk kategori baik. Penyiapan bekal pengetahuan dan keterampilan oleh sekolah sebelum peserta didik melakukan program PKL dengan diadakan guru tamu dari bengkel resmi selama dua bulan untuk memberi gambaran pekerjaan di industri sebelum pembekalan PKL dilakukan. Hal yang perlu ditingkatkan agar tergolong dalam kategori baik sekali adalah penyiapan pengetahuan serta keterampilan peserta didik agar memperlancar dalam proses program PKL dengan cara mematangkan rencana dan memberi guru pendamping yang tetap kepada guru tamu dari industri serta memaksimalkan pemberian keterampilan dan pengetahuan dasar oleh sekolah sebelum program PKL dijalankan di industri. Penguasaan kompetensi oleh peserta didik yang baik akan mempengaruhi proses program PKL. Semakin baik kompetensi yang dimiliki peserta didik maka akan memperbesar kesempatan program PKL bisa berhasil.
3. Evaluasi

Proses

(Process

\section{Evaluation)}

Ada tiga sub variabel dari evaluasi proses pada pelaksanaan PKL di SMK Muhammadiyah 3 Karanganyar yaitu :

Tabel 4.3. Deskripsi Hasil Rata-Rata Aspek Evaluasi Proses

\begin{tabular}{llcc}
\hline No. & Indikator evaluasi & $\begin{array}{c}\text { Rata-rata per } \\
\text { komponen }\end{array}$ & $\begin{array}{c}\text { Rata-rata } \\
\text { aspek }\end{array}$ \\
\hline 1. & Pelaksanaan PKL & 78,62 & \\
2. & Hambatan PKL & 71,93 & 75,47 \\
3. & Relevansi PKL & 75,86 & \\
\hline
\end{tabular}

Hasil penelitian dari tabel 4.3 ditampilkan dalam diagram batang berikut :

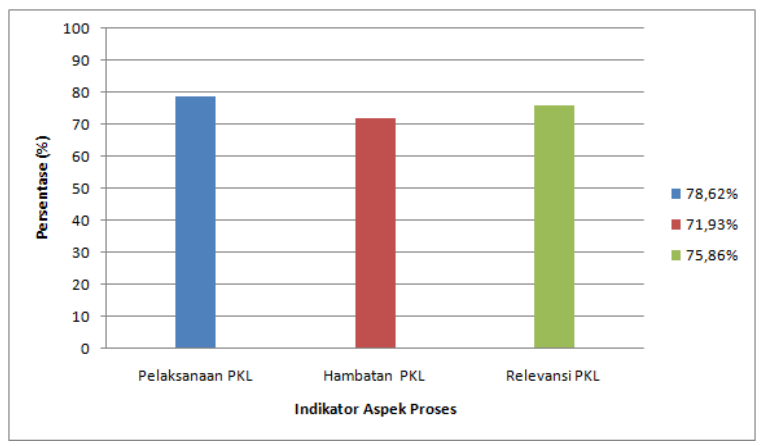

Gambar 4.3. Capaian rata - rata nilai pada aspek evaluasi proses

Berdasarkan hasil penelitian mengenai evaluasi proses pelaksanaan PKL di SMK Muhammadiyah 3 Karanganyar pada indikator pelaksanaan PKL mendapatkan rata-rata $86,11 \%$, hambatan yang ditemui saat PKL memperoleh rata-rata $28,27 \%$. Apabila dikonversi menjadi tidak ada hambatan adalah $71,93 \%$. Serta relevansi program PKL yang sudah 
diberikan oleh sekolah dengan industri mendapatkan rata-rata $75,86 \%$. Ratarata evaluasi proses secara keseluruhan adalah 75,47 \%. Angka tersebut menunjukkan bahwa evaluasi proses program PKL di SMK Muhammadiyah 3 Karanganyar termasuk kategori baik.

a. Pelaksanaan program PKL secara keseluruhan tergolong dalam kategori baik. Pelaksanaan program PKL yang perlu ditingkatkan agar tergolong dalam kriteria baik sekali yaitu dengan meningkatkan peran pembimbing industri dalam membimbing peserta didik saat melakukan proses program PKL. Pembimbing diharapkan memberikan pelayanan kepada peserta didik secara maksimal saaat proses program PKL dijalankan. Pemanfaatan sarana dan prasarana perlu ditingkatkan lagi agar diperoleh hasil yang maksimal. Peran peserta didik saat pelaksanaan program PKL juga perlu ditingkatkan. Peserta didik lebih diberi motivasi agar lebih bersemangat untuk melakukan pekerjaan dan menerapkan ilmu yang sudah diperoleh dari sekolah. Pembimbing industri berperan penting dalam pelaksanaan program PKL. Sejalan dengan (Burhan et al., 2017) menejemen pengawasan dan bimbingan serta metode masalah penilaian adalah faktor yang mempengaruhi pencapaian dalam program PKL.

b. Keseluruhan hambatan yang ditemui saat pelaksanaan program PKL tergolong rendah. Hal tersebut menjadi indikasi bahwa dalam proses pelaksanaan program PKL baik pembimbing industri, guru pembimbing, serta peserta didik tidak menemui hambatan yang besar. Hambatan yang ditemui pembimbing industri adalah pada membimbing peserta didik pada awal program PKL berjalan karena peserta didik kurang aktif dalam merespon pekerjaan dan kurang pengetahuan dalam lapangan. Tetapi setelah program berjalan beberapa minggu peserta didik mulai paham pekerjaan yang dilakukan di industri. Hambatan yang ditemui peserta didik adalah pada waktu awal mulai PKL mengenai penggunaan alat yang menggunakan teknologi modern karena di sekolah belum diajarkan secara maksimal. Namun, setelah mencoba beberapa kali peserta didik bisa menggunakannya. hambatan yang ditemui guru pembimbing adalah ketika membimbing peserta didik yang melakukan PKL di luar kota terkendala waktu dan biaya.

c. Relevansi program PKL termasuk dalam kategori baik. Ada keterkaitan 
antara pengetahuan dan keterampilan yang sudah diberikan oleh sekolah kepada siswa dengan dunia industri tempat program PKL berlangsung. Menurut (Setyaningrum, 2018) Ini merupakan langkah yang efektif dari kurikulum untuk mensinkronkan kompetensi di sekolah dengan di industri sebagai wujud dari program PKL yang merupakan implementasi link and match.

\section{Evaluasi Produk (Product Evaluation)}

Ada empat sub variabel dari evaluasi produk pada program PKL di SMK Muhammadiyah 3 Karanganyar yaitu :

Tabel 4.4. Deskripsi Hasil Rata-Rata Aspek Evaluasi Produk

\begin{tabular}{llcc} 
No. & Indikator Evaluasi & $\begin{array}{c}\text { Rata-Rata per } \\
\text { Komponen }\end{array}$ & $\begin{array}{c}\text { Rata-Rata } \\
\text { Aspek }\end{array}$ \\
\cline { 1 - 3 } 1. & Ketercapaian Tujuan & 87,85 & \\
\cline { 1 - 2 } 2. & $\begin{array}{l}\text { Perkembangan Peserta } \\
\text { Didik }\end{array}$ & 84,99 & \multirow{2}{*}{84,33} \\
\cline { 1 - 2 } 3. & $\begin{array}{l}\text { Kepribadian Peserta } \\
\text { Didik }\end{array}$ & 78,89 & \\
\cline { 1 - 2 } 4. & Kepuasan Peserta Didik & 85,59 & \\
\hline
\end{tabular}

Hasil penelitian dari tabel 4.4 ditampilkan dalam diagram batang berikut :

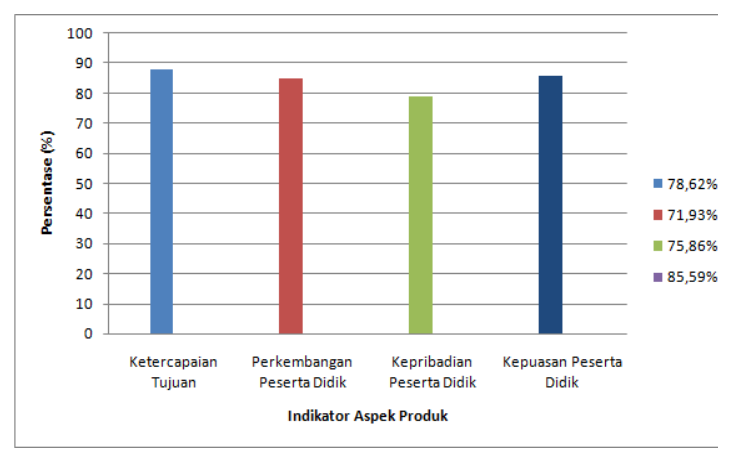

Gambar 4.4. Capaian rata - rata nilai pada aspek evaluasi produk

Berdasarkan hasil penelitian mengenai evaluasi produk pelaksanaan PKL di SMK Muhammadiyah 3 Karanganyar pada indikator ketercapaian tujuan mendapatkan rata-rata $87,85 \%$, perkembangan peserta didik memperoleh rata-rata $84,99 \%$, kepribadian peserta didik mendapatkan rata-rata $78,89 \%$, serta kepuasan peserta didik mendapatkan rata-rata sebesar $85,59 \%$. Rata-rata evaluasi produk secara keseluruhan adalah 84,33\%. Angka tersebut menunjukkan bahwa evaluasi produk program PKL di SMK Muhammadiyah 3 Karanganyar termasuk kategori baik sekali.

a. Pelaksanaan program PKL secara keseluruhan termasuk dalam kategori baik sekali. Artinya bahwa program PKL yang ada di jurusan Teknik Kendaraan Ringan sudah memenuhi tujuan yang dibuat dari awal sebelum program dilaksanakan. Tercapainya tujuan program PKL mengindikasikan bahwa program berhasil.

b. Perkembangan peserta didik termasuk kategori baik sekali. Peserta didik memperoleh pengetahuan, sikap, keterampilan serta pengalaman baru yang 
diperoleh setelah melakukan program PKL. Namun mental peserta didik perlu ditingkatkan lagi agar terbiasa dengan keadaan dunia kerja yang berbeda dengan keadaan di sekolah.

c. Kepribadian peserta didik setelah melakukan program PKL di industri termasuk kategori baik. Perlu adanya peningkatan kedisiplinan, kerajinan serta tanggungjawab peserta didik. Faktor yang mempengaruhi kepribadian peserta didik tersebut selain dari dalam diri peserta didik, tapi dengan lebih memaksimalkan lagi pembimbingan oleh pembimbing pada saat program PKL dijalankan serta memberi nasihat kepada peserta didik pentingnya mentaati aturan tata tertib agar peserta didik lebih termotivasi untuk lebih mengembangkan kepribadian yang dimilikinya.

d. Kepuasan peserta didik terhadap program PKL secara keseluruhan termasuk kategori baik sekali. Hal tersebut menjadi penanda bahwa program PKL sukses dan bisa diteruskan diperiode selanjutnya dengan syarat perbaikan disetiap aspek yang ada sehingga program PKL bisa lebih maksimal.
Berdasarkan empat aspek evaluasi diatas, tingkat pelaksanaan program PKL di SMK Muhammadiyah 3 Karanganyar disajikan pada tabel berikut :

Tabel 4.5. Deskripsi Hasil penelitian Semua Aspek Evaluasi

\begin{tabular}{llcc}
\hline No. & Aspek evaluasi & $\begin{array}{r}\text { Rata-rata per } \\
\text { komponen }\end{array}$ & $\begin{array}{c}\text { Rata-rata } \\
\text { aspek }\end{array}$ \\
\hline 1. & Konteks & 84,67 & \\
2. & Input & 83,14 & \\
3. & Proses & 75,47 & 81,90 \\
4. & Produk & 84,33 & \\
\hline
\end{tabular}

Hasil penelitian dari tabel 4.5 ditampilkan dalam diagram batang berikut :

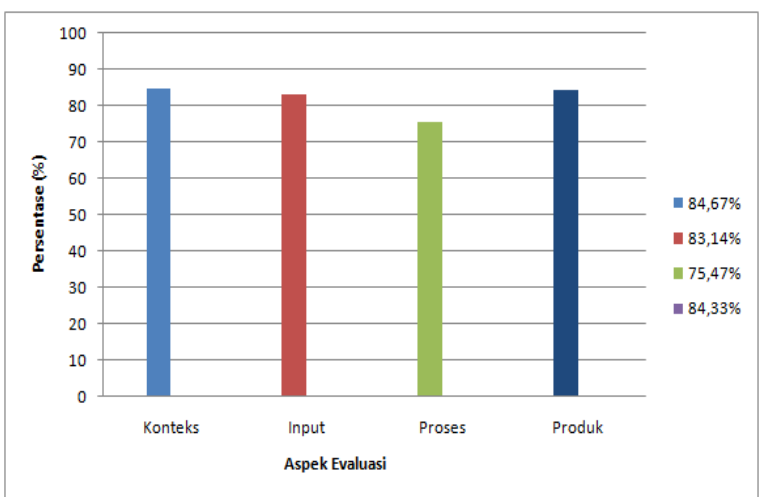

Gambar 4.5. Capaian rata - rata nilai pada semua aspek evaluasi

Pada hasil penelitian mengenai implementasi PKL di SMK Muhammadiyah 3 Karanganyar evaluasi konteks mendapatkan persentase $84,67 \%$, evaluasi input mendapatkan persentase $83,14 \%$, evaluasi proses mendapatkan persentase $75,47 \%$, serta evaluasi produk mendapatkan persentase $84,33 \%$. Rata-rata hasil dari aspek 
evaluasi program adalah $81,90 \%$. Hal tersebut menandakan bahwa program PKL di SMK Muhammadiyah 3 Karanganyar termasuk kategori baik sekali. Didukung dengan analisis hasil penilaian akhir program PKL dari SMK Muhammadiyah 3 Karanganyar mendapatkan rata-rata nilai 85,003. Aspek penilaian total tersebut meliputi rata-rata nilai dari industri, nilai buku kegiatan PKL, nilai laporan program PKL, nilai tes lisan yang dilakukan oleh guru. Rata-rata nilai tersebut tergolong sangat baik dari kriteria yang sudah ditentukan oleh sekolah. hal tersebut menunjukkan program yang dijalankan berhasil.

\section{SIMPULAN}

Hasil evaluasi secara keseluruhan menunjukkan bahwa pelaksanaan program PKL berjalan dengan baik dan lancar. Evaluasi aspek konteks secara keseluruhan masuk dalam kategori baik sekali. Perlu adanya peningkatan karakteristik peserta didik dari segi kesiapan pengetahuan, keterampilan serta minat peserta didik. Evaluasi aspek input program PKL secara keseluruhan masuk dalam kategori baik sekali. Pemilihan tempat industri untuk menjalankan program PKL perlu ditingkatkan dengan membuat MoU dengan industri besar serta penyiapan bekal pengetahuan dan keterampilan dasar juga perlu ditingkatkan. Evaluasi aspek proses program PKL secara keseluruhan masuk dalam kategori baik. Peran peserta didik dan peran pembimbing industri dalam membimbing peserta didik saat melakukan proses program PKL perlu ditingkatkan. Pemanfaatan sarana dan prasarana pada saat proses program PKL perlu dimaksimalkan. Evaluasi aspek produk program PKL secara keseluruhan masuk dalam kategori baik sekali. Perlu adanya peningkatan kedisiplinan, kerajinan serta tanggungjawab peserta didik.

\section{DAFTAR PUSTAKA}

Abdulmajid, N. W. (2015). Pola Pembimbingan Di Tempat Kerja: Studi Kasus Pelaksanaan Program Praktik Industri Di Pt Jmi. Taman Vokasi, 3(2), 761-768. https://doi.org/10.30738/jtvok.v3i2.35 7

Arikunto, S. (2006). Prosedur penelitian Suatu Pendekatan Praktek Edisi Revisi VI. Rineka Cipta.

Arikunto, S. \& J. C. (2009). Evaluasi program pendidikan: Pedoman Teoritis Praktis bagi Mahasiswa dan Praktisi Pendidikan. Bumi Aksara.

Burhan, I. M., Ahmad, A., \& Alimuddin, M. (2017). An Analysis of the Management Problem of Working Practices of Industry in Vocational High School. International Review of Management and Marketing, 7(3), 72-76.

Edi, S., Suharno, S., \& Widiastuti, I. (2017). Pengembangan Standar Pelaksanaan Praktik Kerja Industri (Prakerin) Siswa Smk Program 
Keahlian Teknik Pemesinan Di Wilayah Surakarta. Jurnal Ilmiah Pendidikan Teknik Dan Kejuruan, 10(1), 22-30. https://doi.org/10.20961/jiptek.v10i1. 14972

Hasan, A., Nurulhuda, S., Mohd, T., Fauzi, M., \& Yunus, M. (2015). A Conceptual Framework for Mechatronics Curriculum Using Stufflebeam CIPP Evaluation Model. Procedia - Social and Behavioral Sciences, 195, 844-849. https://doi.org/10.1016/j.sbspro.2015. 06.324

Hasanah. (2015). Entrepreneurship Membangun Jiwa Entrepreneur Anak Melalui Pendidikan Kejuruan. CV. Misvel Aini Jaya.

Muladi, A. P., Wibawa, \& Moses, K. M. (2018). A study of the impact of cooperation between vocational high school and industries in Malang City A study of the impact of cooperation between vocational high school and industries in Malang City.

Musthofa, M. U., Suswanto, H., \& Nyoto, A. (2017). Analisis Praktik Kerja Industri Siswa SMK dalam Menyesuaikan Kebutuhan Dunia Kerja. 244-251.

Muyana, S. (2017). Context Input Process Product ( CIPP ): Model Evaluasi. Prosiding Seminar Bimbingan Dan Konseling, 1(1), 342-347.

Riduwan, A. \&. (2006). Rumus dan Data dalam Analisis Statistika. Bina Alfabet.

Riyanto, J., Akhyar, M., \& Harjanto, B. (2017). Evaluasi Pelaksanaan Praktik Industri dengan Menggunakan Model CIPP pada Program Studi Pendidikan Teknik Mesin Universitas Sebelas Maret Surakarta. Jurnal Ilmiah Pendidikan Teknik Kejuruan, X(2),
$12-23$.

Sardimanto, Yusrizal, \& Niswanto. (2017). Pengelolaan Pelaksanaan Praktik Kerja Industri Pada Jurusan Teknik Kendaraan Ringan di SMK Negeri 2 Banda Aceh. Jurnal Magister Administrasi Pendidikan Pascasarjana Universitas Syiah Kuala, 5(1), 20-29.

Setiyaningrum, D. (2018). Manajemen Praktik Kerja Lapangan Di Smk Batik 2 Surakarta. 13(1), 108-116.

Sofyan, H. (2015). Metodologi Pembelajaran Kejuruan. UNY Press.

Sudira, P. (2012). Filosofi \& Teori Pendidikan Vokasi dan Kejuruan. UNY Press.

Yoto, \& Widiyanti. (2017). Vocational High School Cooperation with PT Astra Honda Motor to Prepare Skilled Labor in Industries. International Journal of Environmental and Science Education, 12(3), 585-596. https://doi.org/10.12973/ijese.2017.12 $49 \mathrm{p}$ 